\title{
Experiment: the Problem of Interference
}

\author{
Leonid S. Chernov ${ }^{\mathrm{a}}$ \\ and Elena Iu. Pogorel'skaia ${ }^{\text {t* }}$ \\ ${ }^{a}$ Ural Institute of Management (Branch) \\ of the Russian Presidential Academy \\ of National Economy and Public Administration \\ 66 Marta 8 Str., Ekaterinburg, 620144, Russia \\ ${ }^{b}$ Humanitarian University \\ 19 Studencheskaya Str., Ekaterinburg, 620049, Russia
}

Received 07.02.2017, received in revised form 16.03.2017, accepted 24.03.2017

This article discusses the problem of scientific experiment as a base of West European culture and scientific rational thinking. Scientific experiment is not only a strict, natural method, but also a universal social practice penetrating into all forms of social life including human nature. The authors examine different kinds of social experiments on the basis of cinema and literature, as well as true evidence of the Auschwitz experiment. The virus nature of technology is supported with examples from modern social life.

Keywords: experiment, a social experiment, scientific method, nature of technology, viral nature, bare life, essence of man, witness.

DOI: 10.17516/1997-1370-0054.

Research area: philosophy.

The classical cosmos was made, or created; therefore, just like people, gods were also works of art, the art of different ontological status. As a man of theory, philosopher works to solve the riddle of the subject he is attracted to. Describing love as a "method" of cognizing ideas, Plato drew on Hesiod who claimed the world impossible without Eros, outlining five types of it/him: erotic love, covetousness, ambitiousness, love for power, and philosophy. Plato understood philosophy as a special kind of love which was later named platonic (Boldygin, 2013: 98). The philosophers carried away with the object of their passion could not or would not cause any harm to this object, torture it with mistrust, being able to look deep into themselves and tune for harmonic interaction with it. However, around loving philosophers there have always been some practical people, such as farmers, craftsmen, merchants, sailors, warriors, politicians, who were interested in a different aspect of the cosmos, the use that can be made of it, not some vague truth. For a philosopher, however, such practicality may destroy the harmony of creation; it explains Pythagoras, Plato and Aristotle's rejection of enlightening people with philosophic truth. With

(C) Siberian Federal University. All rights reserved

* Corresponding author E-mail address: leon-chernov@yandex.ru 
due respect to engineering professions, they have always been treated as a desire to "deceive the inherent nature of things".

Indeed, in such cultural conditions an experiment could not develop as a scientific method of cognizing the truth. It was only at the dawn of the modern age, when the "natures of things" were transformed in a single Nature, and naturalists suggested that the things of nature and tools of cognition may follow the same mechanical law. Basically, both objects of research and the tools used for their study constitute the same world of nature. Consequently, the "mechanical arts" bear no lies; they make up the tools the man uses to reveal the qualities of natural things that are impossible to discover with mere observation. Francis Bacon wrote: “...nature's secrets come to light better when she is artificially shaken up than when she goes her own way" (Bacon, 1972: 61). A naturalist creates a new thing because it is transformed with an embedded gauge. "A thing should be moved away from its natural place, deprived of its natural appearance, drawn from its natural conditions and tried in a number of situation until it reveals itself as a whole object; Therefore, the new science object is not just a result of a traditional thing transformation, in includes the procedure of such transformation into its own self" (Akhutin, 2014: 210). Therefore, the New Age science destroyed and re-built natural things to reveal a universal principle in the artificially organized being. The success of natural science was so convincing that science included the mechanical picture of the world in its arsenal to explain the phenomena of society and man using the same method. Society was compared with clock; man was compared to machine. Social thought began rebuilding reality, shaping it into a new form of "social relations".

European revolutions of the $17-18^{\text {th }}$ centuries demonstrated human will to manipulate the nature of social system. In the $19^{\text {th }}$ century humanities began to speak up, thriving to break free, separate from natural science, but new humanitarian thought failed to change the global paradigm that was discovered in the $17^{\text {th }}$ century, while the seemingly independent and specific, but in fact universally spread new European experimental kind of thinking invaded everything.

Experiment means active interference into a natural process, creating new nature as a result. How appropriate would it be to say that, as Francis Bacon believed, within an experiment nature interacts with itself, if the result of any scientific research is directly caused by some influence made on the object of interest? How possible is it for the experimenter himself both to remain what he is and to preserve the nature he studies? I. Kant claims that the object of research "appears" to a scientist, i.e. demonstrates him some features accordant with the inherent abilities of the subject. It means that our nature does limit the perception and cognition of a thing, as our sensual and intellectual capacity is not unlimited.

The primary human principles of cognition are definite enough, and therefore the object of research "appears" to the man in the way predetermined by his nature. Of course, there are research tools that expand the sensual capacities of man (telescope amplifies vision, acoustic aid modifies hearing). However, interaction of such instruments with the object of research provokes emergence of some symbioses that blur the boundary between the nature of such object and the result of the instrument's influence.

The main peculiarity of experimental attitude to reality is the fact that aggressive influence on the studied object causes transformation and reformation of its nature, and, consequently, gives birth to a new type of nature.

The strongest desire to reform the research object is observed in "structural chemistry" which may be explained as follows. Any chemical 
substance consists of a certain number of atoms of some chemical elements. Knowing the properties of each element and understanding the relations it can form, we can plan the synthesis of new chemical substances with required properties, creating new structural formulae of chemical compositions, and new chemical substances. Ideally, such substances should have the properties and qualities we forecast and want to use. Chemistry works to make substances with certain properties and find ways of managing them.

The $20^{\text {th }}$ century's chemistry gave the humankind new medicines, pigments, rubber, artificial silk and many other things. This example is meant to prove that experimental worldview is not concentrated on conquering nature and making "natural world" serve the cause of the humankind; experimental method assumes creation of new nature, conforming to the man's needs, of controllable nature with "selected properties".

The technical aspect of experiment and research is a direct consequence of scientific worldview. It is impossible to divide science into theory and practice (engineering) or classify experiments, according to Francis Bacon, into illuminating and fruitful. Technology (interference) is the very base of any experiment. The essence of technology (interference, or instrument) is not just expansion of sensual capacities of man, not just "seeing farther and hearing better"; its essence is embedment of something new and different into classical nature. We conclude that implementation of any technology has a viral nature, or, in other words, ability to connect to a nature of thing as to a genetic program in order to transform nature, conquer, enslave it, re-program it for a new task. In this aspect, technology does not mean "liberation" of the nature of thing, revelation of its purpose as it used to be in classical studies. Interference of technology "transforms the appearance" of the primary subject, giving it a "new nature".

Why do we take the liberty of applying technical methods to living beings as easily as science does it to the non-living? Throughout the $20^{\text {th }}$ century, biological theories of life origin have been working to find the way of transforming nonliving matter to the living; such examples can be found in the experiments made by A.I. Oparin and S. Miller. These experiments were based on the hypothesis that the living can originate from the non-living, and, consequently, it is necessary to find the conditions that make it possible. Stanley Miller produced around 20 amino acids, acting as construction material for protein, from non-organic substances in laboratory settings. Obviously, it inspired the academic community and proved that the avenue of search was correct. And though the direct path from the non-organic substance to a living organism has not been found yet, natural science still supports the hypothesis that it may exist.

Modern science creates a new man, transplanting technical mechanisms into the living tissue of Anthropos. Such search and engineering craft require a certain access to the paradigm of thinking. This specific "access" may open due to possible permeability of the qualitative barriers between things. Quantitative consistency and permeability of all the qualities makes the borders between them conventional. There is no qualitative demarcation line not only within life (as evolution theory claims); there is none between the living and the non-living. In the late $20^{\text {th }}$ century genetic engineering came up, providing the opportunity of combining genetic material on the genetic level (such as Walter Gehring's experiments on splicing the genes of rat and drosophila). It means that science aspires to create new biological species, which also involves certain interference into the nature of man. For instance, "an Australian named Stelarc considers 
integration of technical aids into the body as a means of evolutionary development: technologies transplanted into the body on symbiotic principle creates a new type of evolutionary synthesis, a new human hybrid of organic and synthetic, producing a new kind of evolutionary energy. In Stelarc's performance Amplified Body, Laser Eyes and Third Hand the moves of his body were directed by muscle stimulators activated through the Internet. A special amplifier received sounds from inside the body, while the mechanical third arm attached to the artist's right forearm, made various moves throughout the performance, from spontaneous and unpredictable ones to those dictated by the nervous system of the performer" (Tsurr, 2006: 154-155). This example illustrates that similar experiments with human body are technically possible; it also demonstrates the incompleteness/flexibility of a human being both at the physical and spiritual levels, as man is offered changing a lot in his self-perception and self-identification.

As for the officially prohibited though widely spread social experiments, the purpose of so-called "research" is studying the "nature of man" or its essence hidden beneath the dross of ideology, breeding, prejudice and other obscure layers eclipsing the experiment and the true nature of man. Studying human being, science does not follow the paths of love, unsubstantially suggesting that it is the only way of finding the true face and true nature of man. Science prefers proven patterns, which are the methods of experiment. Now let's ask ourselves a question: what is a man in the experiment? The answer is paradoxical: a man in the experiment is regeneration and transformation.

Intentions of science and religion are the same: reformation, transformation of the world nature. However, despite the similarity of intention (social utopia, finding heaven, welfare society), the principles of constructing things are different in religion and science. If religion finds meaning of things by "incrementing" a non-material (spiritual, conceptual, symbolic) component to it, science, withdrawing spirit from nature, transforms the living into merely material. Dealing with potential infinity of matter, it can never expand to the sphere of actual being, to the sphere of purposes of matter itself. It is demonstrated by the example how important it was in the New Age to overthrow the authority of Aristotle, and give things non-purposeful reasons instead of their purposeful reasons, or entelechies. In this new matter, the role of the experimenter (the subject of experiment) himself and the experimented (the object of experiment) are intertwined in such a complicated way, that it becomes impossible to explain, what actually goes on within the experiment. Where is the true evidence of it? Today experiments are conventionally classified into natural scientific and social; however, it would be better to divide them into safe and real (dangerous). In safe experiments, the man is maximally distant from the experiment itself, i.e. he hardly bears any responsibility for the "clarification" of nature and consequences of such "clarification". An example of such safe social experiment is a movie involving the man into the story, but only in the make-believe way. The degree of involvedness determines how real the experiment is, whether it can be taken as a fun toy or not. Real experiments are the ones involving the man completely, happening in real life. Safe experiment assumes that the experimental situation does not cause any memory calling for responsibility. Safe experiments are silly, meaning that they do not involve the human as a whole. Let us provide some examples of "real" experiments, emphasizing the evidence aspect. Isn't it the witness' evidence that is used to distinguish true from false?

Novel Hard to Be a God by Arkady and Boris Strugatsky describes a social experiment 
from the point of view of a gauge, a tool of research which is the man himself. The epigraph of the novel is symbolic: "In this particular show you have to be armed to enforce your authority. But you're not to use your weapon under any circumstances". Don Rumata is required to record everything that is happening without interfering, to be principally objective. The same is required of any thermometer, amperemeter, voltmeter, or tonometer. Does a tonometer worry if one's blood pressure is $220 / 100$ ? We believe that it does not. But what if the "gauge" is the man himself? "The experiment doesn't care what your feelings are. If you can't do it, then keep out of it!" says Rumata to himself, confirming his function of an independent monitor. Let us remind you: being a terran, Rumata presents the position of the future, the actual progressive development position of any terrestrial community. In this sense, from the human point of view, everything happening in Arkanar belongs to the past. The reader can easily identify the historical status of Arkanar as late Middle Ages, i.e. as something that has once happened. Information of the events happening in the past of Arkanar is automatically sent to the Earth through a transmitter in the circlet Rumata wears on his head. From the future, Rumata observes the past; it is his past which is for some reason does not look blissful like the Garden of Eden, but is full of refined atrocity. There are murders and injustice. There is a "no entry" sign on the road leading to the past, so that the future cannot penetrate there. But all road signs can be easily bent; it is nothing but a warning while a man has memory, his way to the past. The future is an observer of the past; it is forbidden to do anything. It may seem that the future has the priority and there are lots of ways of civilized, mild solution of al contradictions: a thousand of excuses can be found for the past. The past realizes it; it knows it will be exculpated. The past believes there are answers to its questions, which makes the past demanding: "Following his miraculous rescue, Arata had ceaselessly demanded explanations. Rumata had once even attempted to tell about himself, he even once showed him Sol, the sun of his planet, in the nocturnal sky - a tiny, hardly recognizable star. But the rebel understood only one thing: The cursed priests were right, gods were indeed living behind the walls of the firmament, omniscient and almighty gods. And from that moment on, every conversation he had with Rumata would always lead to the same point: "God, since you do exist, lend me your strength, for this is the best that you can do for me" (Strugatsky, Strugatsky, 1992: 251). From the point of view of the future, all problems can be solved. We cannot say that Rumata is powerless; he is doing his best to change the situation, saving the best people of the past, scientists, artists, and poets. At the same time, he does not spill a drop of blood, for it is the principal requirement to Rumata and people like him.

But the future cannot use the methods considered normal for the past. For the future, such circumstances are unnatural, for it is formed by other conditions: the common good, absence of diseases or injustice, discrimination or violence, while the past brings rivers of blood. Why would the future need it? The future (Rumata) watches the past (the kingdom of Arkanar) fighting against itself, solving its internal problems, suffering from its internal evil, searching for a way to the future, for an escape from its historical past. "Rumata was overcome by a strange and morbid schism within himself. He knew he was right and yet this awareness humbled him before Arata. Somehow, Arata surpassed him; but not him alone - Arata surpassed all the others that came unbidden to this planet and observed with full impotent pity its teeming life from the lofty peak of passionless hypotheses and alien moral standards. And for the first time Rumata thought: Nothing can be acquired without loss. We are infinitely stronger 
than Arata within our realm of goodness but infinitely weaker than he is within his realm of evil..." (Strugatsky, Strugatsky, 1992: 252).

Voltaire ironically repeats Leibnitz: "All is for the best in the best of all possible worlds", or, in other words, "whatever happens, happens for the best". But someone in the past may clearly say: no, some things cannot be corrected. In the past, Kira died, the most precious person for Rumata; the one who needed to be saved first of all died, his love died. Rumata did his best to remain cold-blooded, "searching for the truth" with Donna Okana, the mistress of blessed Don Reba. Kira did not die by accident or a blind mistake; it happened due to the total negligence of Rumata to the most valuable person in his life. Scientific and experimental quantitative equation of entities (natures, objects, things) leads to false democratization of thinking.

The man is the only full-featured gauge able to remember, i.e. continue the life of the past within himself. The past can be also kept in things, symbol memorials, but they need someone to decipher their messages. For Rumata the past formed a strong axis of torture. Nothing can bring Kira back to life, but Rumata may not kill or forget her in his mind, so he will bear and suffer it. Everything starts one day and then stays forever. If you remember, it means it's not over and it's alive. In the experiment the past is active through active pain. The longer one lives, the more he remembers. The longer one lives, the more he loses, replacing reality with a symbol: "Only that which has died is ours, only ours that which we lost. Ilium was, now Ilium endures in the hexameter that you mourn. Israel was, when there existed an antique nostalgia. Every poem, with time, is an elegy. Ours are the women who left us, no longer subject to an evening that is sinking, to the alarms and terrors of hope. There are no other paradises than paradises lost" (Borges, 1997: 563). Therefore, we are always late to do the first step, as something had already happened before there were us and this common pattern of life where the "real" experiment is taking place. Every time we confront the fait accompli, internal or external, existence is always primary. And the past is close.

For the survivors of Auschwitz, the experiment will never be over. The past never leaves its prisoners, for it always comes back, making them recall it over and over again. The personal trauma caused by the experiment is so severe it can never heal. "It is impossible to wish the eternal return of Auschwitz at least because it never ceased happening, because it is relentlessly repeating. This implacable experience revealed itself to Levi as a dream: It is a dream within other dreams... I'm alone at the centre of a gray, cloudy emptiness, and at once I know what it means, I know that I've always known it: I am once again in the camp, and nothing outside the camp was true. The rest - family, flowering nature, home was a brief respite, a trick of the senses. Now this inner dream, this dream of peace, is over; and in the outer dream, which continues relentless, I hear the sound of a voice I know well: the sound of one word, not a command, but a brief, submissive word. It is the order at dawn in Auschwitz, a foreign word, a word that is feared and expected: 'Get up', 'Wstawac'” (Agamben, 2012: 108-109).

Primo Levi who spent only 11 months in Auschwitz under the number 174517 says that the camp experience is irrevocable, that it is impossible to return to the previous state of peaceful life and start "with a clean slate". Any event leaves its print in a person, and the print of an experiment is always traumatic, since any experiment is never natural, being a continuous process of torture. People cannot recover after experiments. As a witness and as a gauge, a man has memory. Human memory is a document, but it is not anonymous. As far as the camp experiment is concerned, it's a sentence, as it is 
happening in one's present. And let him struggle to escape from the experiment whatever it takes, by all means, by all possible unconscious states (alcohol, specific psychotherapy, hypnosis). In respect to the past, experiment deprives memory of its freedom, since life goes on within the experiment even after it seems over.

The purpose of physical and psychological tortures is control, elimination of any resistance, a clear desire to conquer. But truth/false found as a result of torture does not stand up to any criticism. The words said under torture or in the state of total fear do not make any sense; a person may say anything to stop the pain. Logically, torture is absolutely useless, since it "destroys the conditions under which the statements of the tortured could be taken seriously, truth could be distinguished from false and lies" (Tereschenko, 2011: 133). In other words, torture kills its subject, so there is no one to witness the process, i.e. to make true statements. What torture does within the experiment, is killing any chances of the experiment to reveal the truth. "It is speaking but not saying anything, since it is done not to establish any kind of relations, but to escape from the pain filling the space and the man. Under torture, a man is nothing but pain itself, and his speech is the only way for him not just to say something, but also to avoid the immense suffering that drives him mad, ruins him, ruins him forever" (Tereschenko, 2011: 132). The evidence given under torture is inadequate. Despite their rational and science-like structure, camps were absolutely useless from the point of view of finding the truth.

It is true not only for physical torture, but for any sort of violence ruining personality and destroying the truth, which, as any sort of wholeness, may be only positive. The main thing destroyed in social experiments is human nature, the elusive condition built upon bare life. Agamben arrives at the conclusion that everything specific to a human is potential in its essence, for it presents potential being, while it is the fact of biological life that it actual. One can lose a man in himself even if he survives. "Before being a death camp, Auschwitz is the site of an experiment that remains unthought today, an experiment beyond life and death in which the Jew is transformed into a Muselmann and the human being into a non-human" (Agamben, 2012: 55). Let us remark that the word Muselmann was used by the prisoners not to refer to a religious Muslim, someone converted to Islam, but another prisoner (Jewish, Russian, Polish, gypsy) who has reached the state of ultimate despair. The word Muselmann happened to mean an "outcast". "The Muselmann is the site of an experiment in which morality and humanity themselves are called into question" (Agamben, 2012: 67).

Turning a human into non-human, the concentration camp destroys the witness of what is happening within the camp (the experiment venue) and the man himself. A witness is a person "who has experienced an event from beginning to end and can therefore bear witness to it", G. Agamben writes in his book "Homo Sacer. Remnants of Auschwitz: The Witness and the Archive" (Agamben, 2012: 15). To some extent, the state of the Muselmann reminds of an epileptic seizure: a paradox of simultaneous presence and absence. Getting evidence from the Muselmann himself is impossible; one can only witness the Muselmann "by proxy", "as an onlooker", witnessing something the witness has not experienced himself.

The problem Auschwitz sets in respect of human nature is philosophically academic and traditional: "Does specific human nature really exist?", "What is the underlying sense of belonging to the human species?"

However, it was found that such sense and such nature do not exist. There is a primary "bare life", while the main form of need is biological. 
"The survivor is therefore familiar with the common necessity of degradation; he knows that humanity and responsibility are something that the deportee had to abandon when entering the camp" (Agamben, 2012: 63). The Auschwitz Experiment proved that human nature can be formed, though forming it with direct tortures is not efficient. Tortures create physically weak and exhausted people who can hardly be used, and ascendancy over such people brings no pleasure for it brings some realization of guilt.

Let us consider another approach to human nature, looking pretty optimistic and "humane" from outside, but also classified as a "real" experiment. The prospect of technological classification as a human in the aspect of human happiness has been thoroughly analysed in the novel "Brave New World" by Aldous Huxley. In the novel, people are produced with the Bokanovsky (assonant with Bacon) process. Bokanovskisation is a series of procedures suppressing ovary development. As a result, instead of one unique embryo, up to ninety-six of them may develop as identical twins. As a result of various influences and manipulations, the embryos are given certain features. All people are genetically designed, even an alpha group is formed. The lower the cast, the lower is physical and intellectual level of an individual. However, the world has the best: universal happiness. To reach this goal, all means are used: right breeding from babyhood using appropriate electric shock treatment, light "soma" drug for keeping spirits high, healthy fitness of free sex. People die easy, while they are young and beautiful; the used human material is disposed in the crematorium, leaving some phosphorous as its tribute to scientific progress. "Fine to think we can go on being socially useful even after we're dead" (Huxley, 1988: 45). Happiness turns into an economic category. "But industrial civilization is only possible when there's no self-denial. Self-indulgence up to the very limits imposed by hygiene and economics. Otherwise the wheels stop turning" (Huxley, 1988: 115). The only "inappropriate" element of this world is John the Savage, who did not get technically processed and was born "shamefully" as a regular man. No matter how hard they tried to enlighten him or bring his primeval nature to appropriate state, in some cases both science and democracy are ignorant. There are people who do not wish to simplify! The Savage preferred to live with pain and memory, and, therefore, remained historical and died in the end.

Though the novel "Brave New World" was written by A. Huxley back in 1931, the prophecy of the novel has not been heard yet. Today we keep reading and hearing ideas appropriate for that book as statements and theses of the near future. Here is one example: "What is going to happen next. They will know what we want to buy even before we know it ourselves. Someone will know who we shall marry even before we know it. There are methods to predict in which country a war is about to start. It is interesting that the world is approaching it. To conclude, we will keep on buying and paying, and the goods will be automatically delivered with a smile, and the advertising will be in our heads, and everything will be known of us. It is a fact; we need to accept it, live it, and enjoy shopping" (E-commerce...). This statement is the quintessence of the lecture of Danny Perekalsky, the CEO of Ozon Group, broadcast by Malina channel within Intellectures project on 13.12.2016. The sincerity and directness of this statement along with the authority of the businessman lecturer convince us that it is quite possible, as such situation is determined with good and humane intentions.

Experiments on changing human nature are often presented as a joke, a game, some entertainment. Is it possible to see anything ominous in something with the reference to the 
Biblical text: "I was blind but now I see..." "The Game" movie by D. Fincher (1997) caused a tornado of applause of both critics and public: what subtle psychology, what an amazing change of a boring, rational, cold-minded, shallowhearted millionaire into an alive, compassionate, loving man. Isn't it a miraculous transformation? However, the request for such transformation didn't come from the depth of the human being. Knowing the life of Nicholas van Orton, his brother Conrad decides to make him a present: the Game that changes the life of every player and never leaves anyone indifferent. Oppressed with loneliness and monotony, Nicholas gets involved into the game just like Faust who, desperate to find the truth, gets into the trap of Mephistopheles. Mephistopheles offers Faust, who is about to commit a suicide, a way to solve his problems. He promises to show the truth, his strongest desire, in exchange for as small thing as his soul. For a potential suicide, ready to give his soul away "for free" out of despair, such agreement seems profitable, or, in other words, rational. Faust accepts it. Nicholas van Orton also has some desires he does not allow into his life. They are driven deep into the subconscious, into his dreams, associations and fears. Indeed, the Game gives him what he wants. In the Game, Nicholas creates real ontological connections to the artificial situations he gets into. It is practically impossible to escape from the Game, for Nicholas gave his suggestive points and keys to his string pullers; he has given away everything his nature is longing for. Trying to keep cold-blooded, Nicholas still gets involved deeper into the game. Just like for Faust, without Mephistopheles the death of Margaret, connection with the dead and many other things would never happen, as all these were fabricated and planned. Having "had enough" of his own desires, Nicholas becomes a kind, compassionate, loving, considerate, and forgiving man as it was planned. But the main thing is that Nicholas van Orton becomes a different person. A person just like everyone else. Just like the two hundred people taking part in the Game. Just like everyone who goes through the Game experiment fairly and completely. There is only one question that remains after the "miraculous transformation": would this nice mister, who has been through a suicide and is feeling absolutely content, be able to go through all these tests again? Or would it be too much for the sterile nature of new Nicholas? The old Faust dies, having gone through the ordeals of his discoveries. God takes Faust's soul to himself. We may only hope that the "brought back to life" Nicholas Van Orton is not a ghost himself.

Fincher does not build a wall between the new and the old Nicholas. He gives the audience the happy end they want. However, we believe that it would have been honest for him to show where the victims of social games really get. The task caused by the loss / blurring / devaluation of human nature is the nature-saving task. "To save" is to fetch something home into its essence, in order to bring the essence for the first time into its genuine appearing" (Heidegger, 1993: 234). Despite the complexity of the task, it is obvious that the first thing to be done is to put the right emphasis and grasp the problem. Many issues remain unsolved as they are consciously mixed in, or as the man does not care for them until it's too late and thinks of them as of some meaningless trifles. Saving human nature is conventionally divided into two elements: saving the existence of human and saving his essence. One of the human paradoxes is that he is always larger than he actually is. The essence of man is formed historically, i.e. freely, even if the existence of man has been predetermined by the Creator from the very beginning. 
Virus is a fragment of a DNA or RNA in a protein coat. Virus is specific for penetrating into the core of a living cell and embedding into its DNA. It is only possible because all information bearing molecules are similar and the DNA of a living cell reads the virus as its own program, begins reproducing it as it would reproduce itself, therefore, destructing itself. Technology is a fragment of man, only one of its faces; technology is a lethal face of man he overmasters. A part of it overmasters the whole.

\section{References}

Boldygin, G.B. (2013) K istorii slova "filosofiia" [To the History of the Word "Philosophy"], In Istina ili pol'za. Izbrannoe [Truth or Use. Selected Works]. LAP LAMBERT Academic Publishing, Germany. 120 p.

Bacon, F. (1972) Sobr.soch. v 2-kh tomakh [Collected Works in 2 Volumes]. Moscow, Nauka. Volume 2. $582 \mathrm{p}$.

Akhutin, A.V. (2014) Istoriia printsipov fizicheskogo eksperimenta. Ot antichnosti do XVII v. [History of the Physical Experiment Principles. From Antiquity to the $17^{\text {th }}$ Century]. [Electronic source]. Moscow, Direct Media, 293 p. URL: //biblioclub.ru/index.php?page=book\&id=228428

Tsurr, I. (2006) Uslozhnionnye poniatiia o zhizni: "poluzhivye suschestva" [Compound Life Terms: "Semiliving Beings"]. Logos 4(55).

Strugatsky, A., Strugatsky, B. (1992) Trudno byt' bogom [Hard to Be a God], In Popytka $k$ begstvu. Trudno byt' bogom. Hischnye veschi veka: povesti [Novels: Escape Attempt. Hard to be a God. Predatory Things of Our Times]. Moscow, Text, 416 p.

Borges, J.L. (1997) Obladanie proshlym [Possession of Yesterday], In Sochineniia v triokh tomakh [Selected Works in Three Volumes], $2^{\text {nd }}$ enlarged edition, Volume 2. Moscow, Polyaris, 639 p.

Agamben, D. (2012) Homo sacer. Chto ostaiotsia posle Osventsima: arkhiv i svidetel' [Homo Sacer. Remnants of Auschwitz: The Witness and the Archive]. Moscow, Evropa Publishing House, $192 \mathrm{p}$.

Tereschenko, M. (2011) O pol'ze pytki: mogut li demokraticheskiye obshchestva ostavat'sya pristoynymi? [On the benefits of torture: can democratic societies remain decent?] Logos [Logos] 1(80), $216 \mathrm{p}$.

Huxley, O. (1988) O, divnyy novyy mir! [Brave New World], In Inostrannaia literatura [Foreign Literature], 4, $256 \mathrm{p}$.

E-commerce: buduschee. Intellektsiia Denni Perekal'ski [E-commerce: the Future. Intellection of Danny Perekalsky (Ozon.ru)] malina.am

Heidegger, M. (1993) Vopros o tekhnike [The Question Concerning Technology], In Vremia $i$ bytie [Time and Being], translated by V.V. Bibikhina. Moscow, $447 \mathrm{p}$. 


\section{Эксперимент: проблема вмешательства}

Л.С. Чернов ${ }^{\text {a }}$ Е.Ю. Погорельская

а Уральский институт управления (филиал)

РАНХиГС при президенте РФ

Россия, 620144, Екатеринбург, ул. 8 Марта, 66

${ }^{5}$ Гуманитарный университет

Россия, 620049, Екатеринбург, ул. Студенческая, 19

Статья анализирует природу научного эксперимента как основу западно-европейской культуры. Научный естественный эксперимент оказывается не просто строгим естественным методом исследования природы, но и всеобщей социальной практикой, проникающей во все сферы сочиума, вплоть до человеческой природы. Авторы рассматривают типы и виды соииального эксперимента на примерах кино, литературы и вопроса об истинном свидетельстве эксперимента Auschwitz. Гипотеза о вирусной природе технического подкреплена примерами жизни современного сочиума.

Ключевые слова: эксперимент, сочиальный эксперимент, научный метод, природа техники, вирусная природа, голая жизнь, сущность человека, свидетель.

Научная специальность: 09.00.00 - философские науки. 